\title{
Heritocide? Defining and exploring heritage crime
}

Louise Grove

Loughborough University, UK

The term heritage crime has been recently brought into the spotlight by English Heritage the organization tasked with protecting England's heritage assets - and is attracting an increasing amount of attention from individuals and organizations from a range of disciplines. Heritage crime includes recognised crime types (such as arson, criminal damage, theft, and graffiti) but arguably has a greater impact on the country's legacy for future generations because of the types of sites affected. This paper presents an initial examination of our understanding of heritage crime, and limitations to that knowledge. The paper contributes an initial typology to facilitate future interdisciplinary discussions of the problems facing heritage assets, and presents a possible route for expanding our ability to tackle this problem. Whilst this is an initial foray into the world of heritage crime, it is hoped that this paper will act as a stimulus for further discussion and action.

Keywords: Heritage crime; situational crime prevention; theft; partnership responses; crime reduction

\section{Introduction}

Heritage crime can be defined as "any offence which harms the value of [a country's] heritage assets and their settings to this and future generations" (English Heritage, 2011a). The characterisation of heritage crime as separate from other criminal acts is a recent development. In consequence very little research has directly focused on the issue, although aspects of the topic, such as theft of art and cultural objects, have been actively researched (for example, see Bernick, 1998; Blum 1995). This article attempts to bring together existing work in this area and lay the groundwork for future research. In what follows, the examples are drawn predominantly from England, due to the focus on specific forms of heritage crime that has emerged there since 2009. The term 'heritage' is used here in a specifically tangible sense, of items and places which can be protected physically, rather than more elusive concerns such as the preservation of cultural memory through, for example, recording and maintaining the use of endangered languages.

There are over 1 million designated heritage assets in England, with the majority owned by private individuals (Shopland, 2010). Assets are defined by English Heritage (n.d.a), the non-governmental body tasked with their protection and preservation, as "A building, monument, site, place, area or landscape identified as having a degree of significance meriting consideration in planning decisions, because of its heritage interest". Assets may be designated (i.e. afforded specific recognition and protection in law), or undesignated, for example those which are locally recognised as having importance. These records are held by local councils, and to the best of the author's knowledge there is no national estimate of how many non-designated assets are recognised across England. Since 2008, a 'Heritage at Risk' Register has been published annually by English Heritage, which formally identifies designated assets at risk of "neglect, decay or inappropriate development" (English Heritage, n.d.a) a wide range of risks that that are posed to designated heritage assets in England. 
The 2012 Heritage Counts report contended that the proportion of heritage assets at risk varies according to the type of asset: for example, in England 16.6\% of scheduled monuments were considered to be at risk, compared with 3.0\% of Grade I and Grade II* listed buildings (English Heritage, 2012). Heritage can be at risk for a number of reasons, with the focus traditionally on the areas of neglect and development. While the 'Heritage at Risk' register does not currently have a separate module for assessing risk from criminal activity this may change, especially as heritage crime has recently been incorporated into English Heritage's core remit within the 2011-2015 National Heritage Protection Plan (English Heritage, n.d.b).

Heritage crime can broadly cover a wide range of areas. Initially, English Heritage has prioritised the prevention and detection of:

- Damage caused to the historic environment

- Unlawful excavation and removal of articles from the historic environment

- Architectural theft

- Unlawful alteration and demolition of listed building

(English Heritage, 2011b)

Repairing damage to heritage assets caused by criminal activity is at best expensive and time consuming. At worst, it may be impossible. The true value of what is stolen may be immeasurable both in financial terms and in terms of the impoverishment of knowledge available to future generations. The term 'heritocide' is coined here to reflect that permanent destruction.

\section{Heritage Crime in England}

To date, there has been relatively little work published which has direct implications for the understanding of heritage crime in England. The evidence of the extent of any problem comes predominantly from anecdotal and one-off reports, rather than any consistent reporting strategy. A small number of groups collect data specifically on heritage incidents, including local authorities, voluntary groups, and some police forces (see Coombes, et al. 2012, for a list of organizations which keep relevant data, with quality assessment). There are methodological problems with accessing data on heritage assets from the Police National Computer (PNC). Specifically, names of heritage assets are usually recorded as they are known locally, rather than the official names as listed on the National Heritage List for England, and there is currently no way of flagging crimes as having a heritage aspect during the crime recording process. This means that there is no automated system to identify heritage crimes within any extant crime database. Manual searches are impractical, and even small-scale searches would struggle to match heritage assets with the addresses as recorded on the PNC. Recent discussions and work has attempted to mitigate the problems.

For example, A 'Controlled Vocabulary' is under development by English Heritage in consultation with relevant heritage sector groups, which is intended to allow the discussion and recording of heritage crimes using the same terminology across all forums (pers comm Mark Harrison, 2013).

Since the National Heritage Protection Plan (NHPP) integrated heritage crime into the core remit of English Heritage for the first time in 2011, there have been further moves towards an understanding of heritage crime. However, this data-gathering is still at an early stage, and as with any new development, is disadvantaged by the lack of public awareness.

Comment [ 1]: You mentioned that a contact told you this. Is it o.k to use Pers Comms here by inserting contact's name? Mark Harrison - I'm not familiar with this way of referencing, so please let me know if you need any more info for the reference list. 
Further, there is minimal academic literature which is directly relevant to the field, with some notable exceptions. Perhaps the most extensive work has been carried out on looting and the related illicit trade in cultural and heritage artefacts (for an overview of research in this area see Brodie, 2012).

The English Heritage Strategic Assessment (Shopland, 2010) drew attention to the need for risk assessment, and highlighted the many types of offence which may be committed at or to a heritage asset ${ }^{1}$. A significant step forward has been taken with the release of the English Heritage report on the nature and extent of heritage crime in England (see Coombes, et al., 2012). This was the first wide-ranging research project on the topic, and surveyed owners, tenants and managers of heritage assets in England. The report estimated that around 75,000 crimes had occurred to heritage assets within a 12-month period, the bulk of which occurred at listed buildings. Criminal damage was by far the most common type of heritage crime identified. The survey struggled to find sufficient data on some asset types, such as protected marine wreck sites and registered parks and gardens to draw statistically valid conclusions within these subtypes of heritage assets. It is therefore likely that the headline figure may underestimate the true extent of heritage crime. However, it provides the most robust data on heritage crime currently available.

\section{Principal types of heritage crime}

\section{Metal detecting}

Prior to the release of the report by Coombes et al., illegal metal detecting, sometimes called 'nighthawking' had perhaps attracted the most attention, particularly since the publication of the Oxford Archaeology report (2009) on the problem, which examined the problem of illegal metal detecting and identified a number of hotspots of criminal activity at heritage assets, both listed and non-listed. The term 'nighthawking' in itself is controversial, and there is a need to move towards using less emotive terminology in this context. The preferred term is emerging as 'theft equipped with metal detectors'. Concern about 'theft equipped with metal detectors' in the UK has stretched back for decades with campaigns in the 1970s and 1980s to update Treasure legislation in response to issues of looting (see for example, Butcher \& Gill, 1990; Thomas, 2009; 2012). However, metal detectorists themselves have struggled with the implications of such attention. The majority of participants in this hobby are law abiding, yet historic interactions with archaeologists such as during the STOP campaign has created wariness and they express understandable concerns about the possibility that any attempt to crack down on illegal activity may have an adverse impact on their rights (Thomas, 2012). It is essential to engage with this knowledgeable group, and use their expertise in order to help prevent thefts where a metal detector is used as a tool in crime.

\section{Lead theft}

Lead theft has drawn an increasing amount of attention in recent years. Churches appear to be particularly vulnerable to this, perhaps in large part because there are a significant number of churches of which lead roofing is frequently a feature. The Church of England published a report on this problem in 2011 which revealed that the number of claims to Ecclesiastical Insurance had risen from 6 in 2003, to 1763 in 2010. The cost of insurance claims for individual churches has consequently risen from around $£ 18,000$ in 2003 to over f3.3 million in 2010 (Church of England, 2011) although there is some suggestion that this 
figure has since fallen (Ecclesiastical, n.d.). Many churches are under-insured and cannot claim the full cost of repair. Marshall (2011) presents the cost of such metal theft to Anglican churches as $f 19$ million between 2007 and 2009. These churches are left to raise money from their parishioners or remain unable to repair the damage. For example, St Helen's Church in Waddington recently raised $£ 15,000$ from its parishioners to replace the roof after it was repeatedly targeted by lead thieves (Robinson, 2014). There is inevitably a broader impact of these crimes as churches can often form the focal point of a community, both in social and spiritual terms. Price, et al., (in press) have noted that repeat victimisation is a feature of lead theft from churches with isolated churches in particular being targeted. The recent English Heritage report suggested that $14.3 \%$ of (listed) religious buildings were affected by metal theft in 2010-2011 (Coombes et al., 2012). Bennett (2008) points to the rising demand in China and India for the manufacture of lead acid batteries as one of the key drivers of lead prices, and consequently theft of lead.

Other crime types also affect heritage assets, and any brief search of news articles will highlight hundreds of examples. Although not a comprehensive list of crimes which can be experienced by heritage assets, what follows hopefully serves in brief as an indication of the range of incidents which may be experienced at a heritage site.

- Metal theft (beyond the lead theft discussed above) is often associated with heritage assets. Any high value metal is a potential target, and in 2012 a single police raid of a London scrap yard recovered 150 brass memorial plaques and a bronze statue worth £3500 (The Telegraph, 2012).

- Structural and architectural theft in general presents a problem for heritage assets, for example the theft of tiles, fireplaces, paving flags, and milestones.

- Anti-social behaviour (including, for example, drug abuse, graffiti, litter, and intimidating behaviour) causes real distress to owners and users of heritage assets, and can sometimes cause physical damage.

- Unauthorised changes and demolition of listed buildings. These may be carried out by the owner or occupier, and whilst the nature and extent is poorly understood, minor changes can go unreported or undetected for many years, particularly in respect of property to which there is no public access.

\section{International heritage crime}

Internationally, much of the focus has been on art theft and the illegal trade in archaeological objects, rather than the broader definition of heritage crime as adopted by English Heritage. Internationally, databases such as the Art Loss Register ${ }^{2}$ and the ICOM red list $^{3}$ provide a record of stolen art and archaeological artefacts in an attempt to protect the world's cultural heritage. There currently is no such equivalent for heritage crime more broadly. In 1995, Richard Blum made the case for making art and heritage crime a priority for international enforcement. He deplored the lack of evidence available, and cited estimated figures of \$1 billion to \$2 billion for the cost of art crime, whilst suggesting that "Turkey alone estimates its annual archaeological treasure loss at \$100m" (Blum, 1995: 150). 
The picture in recent years is not much improved. Benson (2011) refers to the lack of statistics available to determine the true extent of heritage crime in South Africa, and whilst accepting that there are other policing priorities, suggests the need for a specialist policing team to address the problem. According to Kobylinski and Szpanowski (2009) 'treasure hunting', which destroys archaeological sites, was almost unknown in Poland until the mid1990s. It is now one of the greatest threats to the archaeological heritage of Poland (Banasiewicz \& Ginalsk, 1997: 42-44). A small number of authors have linked the rise in metal detecting, both legal and illegal, across various countries to the availability of cheap metal detectors (see, for example, Cornelison Jr \& Smith, 2009; Kobylinski and Szpanowski, 2009). This is entirely consistent with current theories that opportunities directly cause crime (see, for example, Felson \& Clarke, 1998).

\section{A Heritage Crime Typology}

It may be useful here to consider three classifications of heritage crime, which I will term as 'targeted' heritage crime, 'incidental' heritage crime and 'heritage-specific offences'.

'Targeted' heritage crime is that in which the heritage site is targeted specifically for its heritage features. This generally encompasses acquisitive crimes: heritage features such as fireplaces and statues, art and books, which can be sold on, are removed; treasure hunters seek trophies to keep or trade. It may also include crimes of a political nature or iconoclastic acts where heritage assets are targeted to make a specific statement. In contrast, 'incidental' heritage crime does not have strong features associated with the heritage status of the site. Instead, the site has other features which are attractive to offenders. For example, anti-social behaviour may be located at a particular heritage asset because it provides shelter from poor weather. Likewise, offenders using off-roading vehicles may be attracted to a site because the topography poses a particular challenge, rather than because of its archaeological status. This does not minimise the damage caused, but does allow us to understand that we may be able to divert the offenders to a more suitable site. Finally, 'heritage-specific offences' are those which would not exist in law if it were not for the heritage status of the asset. These include, for example, unauthorised changes to or demolition of listed buildings.

We need to differentiate between these three categories of heritage crimes because of their implications for crime prevention. Some 'incidental' or 'heritage-specific' crimes may be tackled by effective education and information programmes. However, this is less likely to be effective where the offender has specifically targeted the heritage asset. Many situational crime prevention measures may be effective regardless of offender motivation.

\section{Heritage Crime Data}

Perhaps the most significant challenge facing individuals and groups attempting to research and address heritage crime is the lack of available data. Heritage crimes may not be recorded for several reasons. The crime needs to be recognized as such, and many assets are remote and uninhabited, which means there is less opportunity for an owner, manager, or tenant to notice, for example, damaged or missing items. The person responsible for the asset may be the offender, particularly in the case of unauthorised changes to the building's fabric. An offence may not be recognized, or may be seen as minor, either by the victim or by the police in attendance (Shelbourn, in press, uses the example of the dismissal of evidence of illegal metal detecting by police by identifying that they see 'only a hole in a 
field'). This latter issue might be addressed through specific training and awareness events, both for professionals and the general public.

Presently, heritage crime is not recorded as a separate crime on police databases (Shelbourn, in press). This presents a particular challenge as crimes which occur on heritage sites are not readily identified as such by any other means. Police systems do not routinely list properties or sites as being of specific heritage interest. Coupled with the different ways in which addresses may be recorded, this makes the task of linking crimes with heritage assets extremely time consuming.

For many crimes, where official police figures are not appropriate for use, victim surveys provide a way to fill in the blanks (such as the Crime Survey for England and Wales ${ }^{4}$ ). However, due to the vast range of heritage assets, many of which are unoccupied, victim surveys are limited in use for heritage crime. The Coombes, et al., (2012) survey is the only comprehensive effort to address multiple crime types the present author is aware of. Existing victim surveys do not incorporate questions about heritage.

Until data collection is addressed, many questions are unanswerable. Chief amongst these are the trends in heritage crime, and the relative risks of various assets. Trends in crime are important to ascertain. In general terms, crime in the UK has been falling since the mid-1990s, but there are some important sub-trends which can give an indication of ways in which to address specific crime types. Identification of these sub-trends can provide important information about policing priorities and preventive strategies. For example, Sidebottom, et al., (2011) noted an increase in metal theft running counter to other theft trends, and identified a significant correlation between (lagged) copper prices and the theft of copper cabling, which in turn suggests a market reduction approach may be beneficial. Using data to assess relative risks of assets (i.e. which asset types and locations are at greater risk of various offences), likewise, can identify where resources should be targeted to most effectively reduce risk. In the immediate term, it may be possible to identify some patterns of heritage crime.

\section{Patterns of heritage crime}

No current literature of which the author is aware specifically addresses patterns of crime present across heritage sites. However, the broader criminological literature can be extrapolated. The most salient literature is that which is based around opportunity theories (Felson \& Clarke, 1998, provide an excellent overview) and the rational choice meta-theory (see, for example, Cornish \& Clarke, 1986). The discussion here is limited to the particular relevance of repeat victimisation and crime pattern theory to heritage crime.

Crime Pattern Theory was developed by Brantingham \& Brantingham (1981) and describes how crime is clustered (see also, Brantingham \& Brantingham, 2008). Much of the theory centres on the routine activities of offenders and victims which create opportunities for crime. The theory contends that most people have a set of primary 'nodes' (for example home, work, shopping and entertainment) and tend to take the same routes between them - these are the 'activity spaces', or paths. "Crimes are likely to cluster around these activity spaces," (Brantingham \& Brantingham, 2008: 85). Heritage sites form part of many people's routine activities - at least 50.4 million visits were made to England's heritage attractions in 2010 (English Heritage, 2011b). They therefore may become a hot spot for criminal activity. Hot spots were first identified by Sherman et al. (1989), who showed that $50 \%$ of calls to police in Minneapolis, Minnesota, were generated in 3\% of locations (see also, Sherman, 1995). Hot spots have become an important tool in locating crime prevention initiatives. 
Crime mapping allows crime patterns, such as hot spots, to be visually represented in user friendly packages - although police may have a rough knowledge of high crime areas, the use of crime maps allows pinpoint accuracy (Anselin, et al., 2008).

Applying this notion, a small number of heritage sites will experience a disproportionate amount of crime, as what may be termed a 'risky facility' (see Eck, et al., 2007). This links specifically with the notion of repeat victimisation, defined as taking place "...when the same person or place suffers from more than one incident over a specified period of time" (Bridgeman \& Sampson, 1994: 2). It is now widely accepted that this past victimisation is one of the best predictors of future victimisation (Sagovsky \& Johnson, 2007). With strong implementation (i.e. that the intervention planned is carried out) and a high implementation rate (that the intervention is given to a large proportion of victims), it is therefore possible to prevent crimes by targeting resources appropriately (Grove, 2011; Grove \& Farrell, 2012). Anticipating repeat victimisation is therefore one of the most important tools we have - the ability to predict where a crime is likely to happen, and hence to protect. Work is underway to develop accurate crime prediction modelling based on the knowledge that offenders are likely to return to the same sites, or those which share geographical proximity or other similar characteristics. Johnson, et al. (2008) successfully tested one such method in relation to predicting domestic burglary. There seems no reason why similar techniques could not be developed for use with heritage crime prediction and prevention.

\section{Current partnership responses to heritage crime in England}

There have been a number of efforts to develop partnerships working to tackle heritage crime in England. The local authority area of Cheshire West and Chester (CWAC) is often held up as an exemplar of early implementation and success. In April 2012, CWAC set up the first 'Heritage Watch' scheme in the country, in association with Cheshire Constabulary, Cheshire Fire and Rescue and English Heritage. This has been established along similar lines as Neighbourhood Watch schemes, and aims to work with owners, managers, tenants and visitors to improve surveillance of and communication between heritage assets. More information of their projects can be obtained from their website and blog (see CWAC, 2012).

A Memorandum of Understanding (MoU) was established between English Heritage, the Crown Prosecution Service and the Association of Chief Police Officers in 2011. Other enforcement bodies may sign up to this in due course. The MoU encourages information sharing and partnership working to address heritage crime. It lays the groundwork for facilitating enforcement responses and grants legitimacy to other proceedings.

The Portable Antiquities Scheme (PAS) provides a code of practice ${ }^{5}$ for responsible metal detecting. It encourages the voluntary recording of archaeological finds in England and Wales and aims to actively engage with metal detector users to encourage responsible use and encourage good practice (Bland, 2009). The efficacy of the PAS overall is open for debate (see Gill, 2010 for a discussion) not least because it does not directly address those individuals who use metal detectors for theft. Bland (2009) notes that there has not yet been an evaluation of the initiative, although independent reviews of the scheme have been positive.

The Scrap Metal Dealers Act was implemented at the beginning of October 2013, making it illegal to sell metal for cash, and introducing licensing for dealers. Cashless transactions and increased regulations on disposal routes increase the effort for offenders 
and reduces the benefits of their theft. There is precedent for this type of approach in England with, for example, the Nottingham City Council Act 2003, which requires all second hand sellers in the city to be registered with Trading Standards in order to reduce theft by targeting possible disposal routes (an example of the Market Reduction Approach - see Sutton, 2010).

The Alliance to Reduce Heritage Crime (ARCH) was formed in 2011 from interested bodies - from across academia, enforcement agencies, local authorities, and the voluntary sector. Annual conferences and an informal information sharing agreement are at the heart of this network with all parties working towards the reduction of heritage crime. There were over 100 members by the time of the second annual conference of ARCH in March 2012. Voluntary bodies are often in a relatively strong position. Even where they struggle to raise sufficient funds, they have existing networks and volunteers to call on for assistance to monitor, repair, and protect heritage sites. However, many heritage assets are unmanned, and have no identifiable custodian, and little interest from the local community. These may be some of our highest risk sites, where the least motivation exists to address crime problems.

\section{The promise of situational prevention for heritage crime}

Crime is caused by opportunity (Mayhew, et al., 1976; Felson \& Clarke, 1998) and these opportunities can be blocked in order to reduce crime. It may be more cost effective to prevent crimes rather than to repair damage after the event (Welsh \& Farrington, 1999). This is particularly true for heritage crime, where it is important to preserve sites for future generations, and detecting offenders after the event means the damage may already be irreparable. It is therefore essential to move from a reactive to a proactive response to these crimes. Although to date there have been no major trials of heritage crime prevention, lessons can be drawn from elsewhere in the academic literature. Once data has been more widely collected and patterns of heritage crime identified, these preventive strategies can be applied to heritage crime.

Crime Prevention through Environmental Design (CPTED) concentrates on how the relationship between people and their environment can affect crime. Situational crime prevention (SCP) likewise addresses the immediate criminogenic environment. Concepts traditionally included in the CPTED approach are those of territorial reinforcement, natural surveillance, and natural access control (Cozens, 2008). These use physical attributes of an area to (respectively): promote a sense of ownership; increase observation of potential offenders; and informally prevent access to potential targets. More recently CPTED has been expanded to include target hardening, space management, and activity support (Cozens, 2008). Target hardening involves the provision and upgrading of physical security measures. Space management refers to the upkeep of the physical environment, in order to promote perceptions of ownership and protection. Activity support provides specific areas where legitimate activities are encouraged. Although much of the work in CPTED has to date focused on residential areas, there is no reason why the principles could not be transferred successfully to heritage sites. Indeed, many assets exist within residential areas, and the spaces are thus not discrete.

The twenty-five techniques of situational crime prevention (see CPOP, 2014) may be used to facilitate crime prevention at heritage assets. These techniques are designed to 
increase the effort, reduce the rewards, increase the risk, reduce provocations, and remove the excuses, of committing offences.

Different strategies need to be employed depending on the site and crime type in question. Rather than reinventing the wheel, many techniques can be adapted from existing crime prevention programmes. For example, Operation Fragment, the 2009 Tilley Award ${ }^{6}$ winner provides an appropriate response to the problem of metal thefts which equally applies to heritage sites (see Edgington, 2009). With the scrap dealers on side, and spot checks in operation, the ability of scrap metal thieves to dispose of stolen metal was greatly reduced, thus de-incentivising the theft in the first place. In the areas this was trialled, the metal thefts fell dramatically at a time when the price of scrap metal was at an all-time high.

Crime prevention techniques which may work for one crime or location may not be transferrable to another. For example, the provision of security lighting may act as a deterrent where there is the possibility of illegal activity being observed and reported immediately, but in contrast may be appealing to graffiti artists (Weisel, 2002). The importance of tailoring the response to the specific crime problem is therefore paramount (see Grove, 2011; Grove, et al., 2012).

\section{Conclusion}

Heritage crime is an area rapidly attracting attention worldwide (see Grove \& Thomas, in press). The enthusiasm surrounding heritage crime detection, prevention, and partnerships has, however, had been tempered by the lack of data surrounding the threat of heritage crime.

A first step towards addressing this lack of data was made with the release of a report on the nature and extent of heritage crime in England over a twelve-month period (see Coombes et al. 2012). Crime prevention guidance tailored to heritage assets was released by English Heritage in 2012. However, this is a new area for research, and these preliminary examinations cannot hope to offer all the answers. Risk profiling of sites, developing improved recording and collation mechanisms, and working with innovators to create new prevention technologies are just some of the items which desperately need attention. There is an urgent need to examine the issues of heritage crime in other countries, and to share experiences of best practice.

The purpose of this paper has been to introduce the relatively new area of heritage crime to those who may have heard the term but not yet realised the significance to them. Heritage crime is a significant problem which has only recently been identified as a core risk to our heritage assets, and would benefit from the attention of interdisciplinary groups working in partnership to address the issue. It is hoped that this paper will alert practitioners, policy makers and academics to recent developments in this rapidly emerging field and serve as a starting point for further debate, discussion and collaboration.

\section{Bibliography}

Anselin, L., Griffiths, E. \& Tita, G. 2008. Crime mapping and hot spot analysis. In R. Wortley and L. Mazerolle, eds. Environmental Criminology and Crime Analysis. Devon: Willan Publishing

Banasiewicz, E. \& J. Ginalski 1997. Poszukiwacze skarbów jako zagrożenie dla dziedzictwa archeologicznego, Poznańskie Zeszyty Archeologiczno-Konserwatorskie. (6): 42-44. 
Bennett, L. 2008. Assets under attack: metal theft, the built environment and the dark side of the global recycling market. Environmental law and management, 20: 176-183.

Benson, B. 2011. Heritage Crime as the Illegitimate Sibling of the South African Crime Family. Acta Criminologica 24(1): 83-95.

Bernick, L.L. 1998. Art and Antiquities Theft. Transnational Organized Crime, 42: 91-116

Bland, R. 2009. The development and future of the Treasure Act and Portable Antiquities Scheme. In Thomas, S. and P. Stone eds. Metal Detecting and Archaeology, Suffolk: Boydell \& Brewer Ltd, pp. 63-86.

Blum, R. 1995. Art and Cultural Heritage Loss: A Worthy Priority for International Prevention and Enforcement. Journal of Financial Crime, 3 (2): 149-152.

Brantingham, P.J. \& Brantingham, P.L. 1981. Notes on the Geometry of Crime. In P.J. Brantingham and P.L. Brantingham, eds. Environmental Criminology (1991 Reissue). Illinois: Waveland Press

Brantingham, P, J. \& Brantingham, P, L. 2008. Crime Pattern Theory. In: R. Wortley \& L. Mazerolle, eds. Environmental Criminology and Crime Analysis. Cullompton: Willan.

Bridgeman, C. \& Sampson, A. 1994. Wise After the Event: Tackling Repeat Victimisation. [accessed 01 May 2014]. Available at:

http://webarchive.nationalarchives.gov.uk/20110220105210/rds.homeoffice.gov.uk/rds/pdfs2/ah37 9.pdf

Brodie, N. 2012. Uncovering the antiquities market. In: R. Skeates, C. McDavid and J. Carman, eds. The Oxford Handbook of Public Archaeology. Oxford: Oxford University Press, pp. 230-252

Butcher, K., \& Gill, D. W. J. 1990. Mischievous pastime or historical science? Antiquity 64: 946-50.

Cheshire West and Chester Council (CWAC). 2012. Heritage Watch. [Accessed 15 April 2012] Available at: <http://heritagecrime.blogspot.co.uk/2012/04/working-with-our-partnerscheshire.html>.

Center for Problem-Oriented Policing (CPOP). 2014. Twenty Five Techniques of Situational Prevention. [accessed 01 May 2014]. Available at: www.popcenter.org/25techniques

Church of England. 2011. Church Buildings Council: Report of the working party on metal theft. [accessed 01 May 2014]. Available at: http://www.blackburn.anglican.org/images/Parish\%20Support/2011metaltheftcbc.pdf

Coombes, M., Bradley, D., Grove, L., Thomas, S. \& Young, C. 2012. The extent of crime and anti-social behaviour facing designated heritage assets. [accessed 01 May 2014]. Available at: https://www.english-heritage.org.uk/content/imported-docs/p-t/researchpaper.pdf

Cornelison Jr, J.E. \& G.S. Smith. 2009. Archaeology, Metal Detecting, and the Development of Battlefield Archaeology in the United States. In: S. Thomas and P. Stone, eds. Metal Detecting and Archaeology. Suffolk: Boydell \& Brewer Ltd. 33-50.

Comment [ 3]: Please provide page numbers for this. DONE 
Cornish, D.B. \& Clarke, R.V. 1986. The Reasoning Criminal: Rational Choice Perspectives on Offending, New York: Springer-Verlag

Cozens, P. 2008. Crime Prevention Through Environmental Design. In: R. Wortley and L. Mazerolle, eds. Environmental Criminology and Crime Analysis. Devon: Willan Publishing

Ecclesiastical. n.d. Metal Theft Falls but the Risk Remains. [accessed 29 April 2014]. Available at: http://www.ecclesiastical.com/churchmatters/news-and-faqs/useful-information/articles/big-dropin-metal-theft/index.aspx

Eck, J., Clarke, R.V. \& Guerette, R. 2007. Risky Facilities: Crime Concentration in Homogeneous Sets of Facilities. In G.Farrell, K.J. Bowers, S.D. Johnson and M. Townsley, eds. Imagination for Crime: Crime Prevention Studies 21. Monsey, NY: Criminal Justice Press, pp. 225-264

Edgington, M. 2009. Operation Fragment. Tilley Award Winner 2009. [accessed 12 April 2012]. Available at: http://www.popcenter.org/library/awards/tilley/2009/09-06\%28W\%29.pdf

English Heritage. n.d.a. Heritage at Risk. [accessed 28 April 2014]. Available at: http://www.englishheritage.org.uk/caring/heritage-at-risk/

English Heritage. n.d.b. National Heritage Protection Plan. [accessed 01 May 2014]. Available at: http://www.english-heritage.org.uk/publications/nhpp-plan-framework/nhpp-plan-framework.pdf

English Heritage 2011a. Heritage Crime [accessed 15 April 2012]. Available at http://www.englishheritage.org.uk/professional/advice/advice-by-topic/heritage-crime

English Heritage 2011b. English Heritage Calls on Communities to Help Tackle Heritage Crime. [accessed 18 April 2012]. Available at: http://www.english-heritage.org.uk/about/news/643873/

English Heritage 2012. Heritage Counts 2012: England. London: English Heritage

Felson, M. \& Clarke, R.V. 1998. Opportunity Makes the Thief: Practical Theory for Crime Prevention, Police Research Series Paper 98. London: Home Office

Gill, D. 2010. The Portable Antiquities Scheme and the Treasure Act: Protecting the Archaeology of England and Wales? Reply to Austin, Barford, Moshenska, Renfrew and Worrell. Papers from the Institute of Archaeology, 20: 33-40.

Grove, L. 2011. Preventing Repeat Domestic Burglary: A Meta-Evaluation of Studies from Australia, the UK, and the United States. Victims \& Offenders, 6 (4): 370-385

Grove, L. 2012. Heritage Crime: Preventative Measures. ARCH Conference presentation 21 March 2012, London.

Grove, L. \& Farrell, G. 2012. Preventing Repeat Victimization. In: B. Welsh and D. Farrington, eds. The Oxford Handbook on Crime Prevention. Oxford: Oxford University Press

Grove, L. E., Farrell, G., Farrington, D.P. \& Johnson, S.D. 2012. Preventing Repeat Victimization: A Systematic Review. Report prepared for the Swedish National Council for Crime Prevention. [accessed 01 May 2014]. Available at: 
http://www.bra.se/download/18.1ff479c3135e8540b29800015728/1340094867269/2012 Preventi ng repeat victimization $2 . p d f$

Grove, L. and S. Thomas (in press). Heritage Crime: Progress, Prospects and Prevention. London: Palgrave Macmillan

Johnson, S.D., Bowers, K.J., Birks, D. \& Pease, K. 2008. Predictive Mapping of Crime by ProMap: Accuracy, Units of Analysis and the Environmental Backcloth. In: D. Weisburd, W. Bernasco and G. Bruinsma, eds. Putting Crime in its Place: Units of Analysis in Spatial Crime Research, New York: Springer.

Kobylinski, Z. \& Szpanowski, P. 2009. Metal detector users and archaeology in Poland: the current state of affairs. In: S. Thomas and P. Stone, eds. Metal Detecting and Archaeology. Suffolk: Boydell \& Brewer Ltd.

Marshall, I. 2011. Cheshire West and Chester Heritage Crime Initiative - Factsheet. [accessed 12 December 2011]. Available at:

http://www.cheshirewestandchester.gov.uk/visiting/heritage/heritage crime.aspx

Mayhew, P., Clarke, R.V.G., Sturman, A., \& Hough, J.M. 1976. Crime as Opportunity. Home Office Research Study No. 34. London: Home Office

Office of National Statistics (ONS). n.d. Crime Survey for England and Wales FAQs. [accessed 29 April 2014]. Available at: http://www.ons.gov.uk/ons/about-ons/get-involved/taking-part-in-asurvey/information-for-households/a-to-z-of-household-and-individual-surveys/crime-survey-forengland---wales/crime-survey-for-england---wales-faqs/index.html

Oxford Archaeology. 2009. Nighthawks \& Nighthawking: Damage to Archaeological Sites in the UK \& Crown Dependencies caused by Illegal Searching \& Removal of Antiquities. [accessed 01 May 2014]. Available at: http://www.helm.org.uk/guidance-library/nighthawksnighthawking/NIGHTHAWKS2.pdf

Price, V., Sidebottom, A. \& Tilley, N. in press. Understanding and Preventing Lead Theft from Churches. In: L. Grove and S. Thomas, eds. Heritage Crime: Progress, Prospects and Prevention. London: Palgrave Macmillan

Robinson, J. 2014. Waddington community fights against church lead thieves. [accessed 01 May 2014]. Available at:

http://www.lancashiretelegraph.co.uk/news/ribble valley/11176921. Waddington community fight s against church lead thieves/

Sagovsky, A. \& Johnson, S. 2007. When does repeat burglary victimisation occur? Australian and New Zealand Journal of Criminology, 40 (1): 1-26

Shelbourn, C. in press. Improving the Treatment of Heritage Crime in Criminal Proceedings. In L. Grove and S. Thomas, eds. Heritage Crime: Progress, Prospects, and Prevention. London: Palgrave Macmillan

Sherman, L.W. 1995. Hot Spots of Crime and Criminal Careers of Places. In: J. Eck and D. Weisburd, eds. Crime and Place: Crime Prevention Studies Volume 4. Monsey, NY: Criminal Justice Press, pp. 35 $-52$ 
Sherman, L.W., P.R. Gartin \& Buerger, M.E. 1989. Hot Spots of Predatory Crime: Routine Activities and the Criminology of Place. Criminology, 27 (1): 27-56

Shopland, R. 2010. Strategic Assessment October 2010. Report to Heritage Crime Strategic Tasking \& Co-ordination Group. Unpublished.

Sidebottom, A., Belur, J., Bowers, K., Tompson, L. \& Johnson, S.D. 2011. Theft in Price-Volatile Markets: On the Relationship between Copper Price and Copper Theft. Journal of Research in Crime and Delinquency 48: 396-418

Sutton, M. 2010. Stolen Goods Markets. Problem Oriented Policing Guide No. 57. [accessed 01 May 2014]. Available at: http://www.popcenter.org/problems/stolen goods/

Telegraph. 2012. Metal thefts: statue of Christ, crucifix and hundreds of cemetery memorial plaques found in raid on scrapyard. [accessed 29 April 2014]. Available at:

http://www.telegraph.co.uk/news/uknews/crime/9271478/Metal-thefts-statue-of-Christ-crucifixand-hundreds-of-cemetery-memorial-plaques-found-in-raid-on-scrapyard.html

Thomas, S. 2009. The Relationships between Archaeologists and Metal-detector Users in England and Wales: Impact of the Past and Implications for the Future. Newcastle University: Unpublished $\mathrm{PhD}$ thesis.

Thomas, S. 2012. How STOP started: Early approaches to the metal detecting community by archaeologists and others. In: G. Moshenska and S. Dhanjal, eds. Community Archaeology: Themes, Methods and Practices. Oxford and Oakville: Oxbow Books, pp. 42-57

Weisel, D.L. 2002. Graffiti. Problem Oriented Policing Guide No. 9. [accessed 01 May 2014]. Available at: http://www.popcenter.org/problems/graffiti/

Welsh, B. \& Farrington, D. 1999. Value for Money? A Review of the Costs and Benefits of Situational Crime Prevention. British Journal of Criminology, 39 (3): 345-368.

\section{Note on contributor}

Dr Louise Grove is Lecturer in Criminology and Social Policy at Loughborough University. Her research interests include environmental and heritage crime, repeat victimisation, crime trends, and situational crime prevention.

Correspondence to: Department of Social Sciences, Loughborough University, Epinal Way, Loughborough, Leicestershire, LE11 3TU, UK. Email: L.E.Grove@lboro.ac.uk

\footnotetext{
Notes

${ }^{1}$ Crime types included in this report were grouped into the following categories: assault; damage; theft and removal of objects; heritage specific offences; inappropriate use of vehicles; substance misuse; public sex environment; environmental crime; natural environment; nuisance behaviour

${ }^{2}$ Information on the Art Loss Register can be found at: http://www.artloss.com/

${ }^{3}$ Information on the ICOM Red List can be found at: http://icom.museum/programmes/fighting-illicittraffic/red-list/
} 
${ }^{4}$ A victimisation survey established in 1982, now being run on a continual basis with an annual random sample
of around 40,000 households from across England and Wales. It asks about crimes which may not have been reported to or recorded by the police and thus provides a better reflection of the true extent of crime (see ONS, n.d.).

${ }^{5}$ Further information on the Portable Antiquities Scheme can be found at their website:

$<$ http://finds.org.uk/getinvolved/guides/codeofpractice>

${ }^{6}$ The Tilley Awards were established by the UK Home Office in 1999 to recognise excellence in problem oriented policing. Projects which won or were shortlisted are detailed at:

http://www.popcenter.org/library/awards/tilley/ 